\title{
SPATIAL VARIABILITY OF SOIL HYDRAULIC PROPERTIES ON A STEEP SLOPE IN THE LOESS PLATEAU OF CHINA
}

\author{
Wei Hu1,2,3; Ming An Shao²*; Quan Jiu Wang²; Jun Fan²; Klaus Reichardt ${ }^{4}$ \\ ${ }^{1}$ Key Laboratory of Water Cycle and Related Surface Processes, Institute of Geographical Sciences and Natural \\ resources Research, Chinese Academy of Sciences, Beijing 100101, China. \\ ${ }^{2}$ State Key Laboratory of Soil Erosion and Dryland Farming on the Loess Plateau, Institute of Soil and Water \\ Conservation, Chinese Academy of Sciences \& Ministry of Water Resource, Northwest A \& F University, \\ Yangling 712100, Shaanxi, China. \\ ${ }^{3}$ Graduate School of the Chinese Academy of Sciences, Beijing 100039, China. \\ ${ }^{4}$ USP/CENA - Lab. de Física do Solo, C.P. 96 - 13418-900, Piracicaba, SP - Brasil. \\ *Corresponding author <mashao@ms.iswc.ac.cn>
}

ABSTRACT: The understanding of the structure of the spatial variability of soil surface hydraulic properties on steep slopes is important for modeling infiltration and runoff processes. The objective of this study was to investigate the spatial variability of these properties on a steep slope of the Loess Plateau in northwest China. A $9600 \mathrm{~m}^{2}$ area was systematically sampled in a grid of 106 points spaced $10 \mathrm{~m} \times 10 \mathrm{~m}$. Hydraulic properties were determined with a disc infiltrometer under multiple pressure heads $(-15,-9,-6,-3,0 \mathrm{~cm})$ at each sample point. Classical and geo-statistical methods were used for data analysis. The results indicated that the variation of Gardner's $\alpha$ and hydraulic conductivities at all applied pressure heads was moderate and the heterogeneity for hydraulic conductivities increased as the applied pressure head increased. Along the slope, hydraulic conductivities generally decreased downwards, while the Gardner's $\alpha$ fluctuated slightly. The Gardner's $\alpha$ of the shaded aspect of the slope was greater than that of the sunny aspect. The hydraulic conductivities of the shaded aspect were greater at higher pressure heads as compared to the sunny aspect, but lower than those of the sunny aspect at lower pressure heads. Correlation analysis showed a negative correlation between hydraulic conductivity and soil organic matter and clay $(<0.01 \mathrm{~mm})$ contents. Hydraulic conductivities at pressure heads of $-3,-6,-9,-15 \mathrm{~cm}$ varied across the slope and their spatial dependence increased as the pressure head declined. The heterogeneity and spatial dependence of hydraulic properties were larger for the areas with shaded aspect as compared to the sunny aspect, however, as pressure decreased they showed a progressively increasing spatial structure, and their spatial structure behaved increasingly similar in both the shaded and sunny aspects.

Key words: disc infiltrometer, steep sloping land, pressure head, spatial structure

\section{VARIABILIDADE ESPACIALDE PROPRIEDADES HIIDRICAS DO SOLO DE UMAENCOSTA DO “LOESS PLATEAU” DA CHINA}

RESUMO: A compreensão da estrutura da variabilidade especial das propriedades hidráulicas do solo de encostas íngremes é importante na modelagem dos processos de infiltração e de escoamento superficial da água. O objetivo deste estudo foi investigar a variabilidade destas propriedades em uma encosta íngreme do "Loess Plateau" do noroeste da China. Uma área de $9600 \mathrm{~m}^{2}$ foi sistematicamente amostrada em um grid de 106 pontos espaçados de $10 \mathrm{~m} \times 10 \mathrm{~m}$. As propriedades hídricas foram determinadas com um infiltrômetro de disco operando sob múltiplas cargas hidráulicas (-15, -9, -6, -3, $0 \mathrm{~cm}$ ) em cada ponto de observação. Métodos clássicos e geoestatísticos foram empregados na análise dos dados. Os resultados mostraram que a variação do índice $\alpha$ de Gardner e das condutividades hidráulicas em todas as cargas aplicadas foi moderada e que a heterogeneidade das condutividades hidráulicas aumentou à medida que a carga hidráulica aumentava. Na direção do declive, as condutividades geralmente decresceram a jusante, enquanto os $\alpha$ de Gardner flutuavam moderadamente. Os $\alpha$ de Gardner das encostas sombreadas foram maiores do que os das encostas ensolaradas. As condutividades hidráulicas das encostas sombreadas foram maiores para cargas hidráulicas maiores em comparação com as encostas ensolaradas, mas menores que as das encostas ensolaradas para cargas hidráulicas menores. A análise de correlação mostrou uma correlação negativa entre a condutividade hidráulica e os teores de matéria orgânica e argila $(<0.01 \mathrm{~mm})$. As condutividades 
hidráulicas sob cargas de -3, -6, -9, -15 cm variaram em toda encosta e suas dependências espaciais aumentaram à medida que a carga diminuía. A heterogeneidade e a dependência espacial das propriedades hídricas foram maiores para as áreas em encostas sombreadas em comparação com as encostas ensolaradas, entretanto, à medida que a carga hidráulica decrescia, elas apresentaram progressivamente uma estrutura especial mais intensa, e esta estrutura se comportou cada vez mais similar para as encostas sombreadas e ensolaradas.

Palavras-chave: infiltrômetro de disco, encosta íngreme, carga hidráulica, estrutura espacial

\section{INTRODUCTION}

Field measurements of soil hydraulic properties such as soil hydraulic conductivity versus pressure head relationships and pore size distribution parameters, such as Gardner's $\alpha$, are important for the characterization of many aspects of unsaturated soil water flow processes (Bagarello et al., 2005). Recently, several (Mohanty et al., 1994; Logsdon \& Jaynes, 1996) have investigated the spatial variability of soil hydraulic properties, however, most studies have focused on leveled or gently sloping land. Few, if any, studies have spatially analyzed hydraulic conductivity on steep slopes. Furthermore, previous studies have mainly focused on the influence of human activities, i.e. planting (Mohanty et al., 1994), and wheeling (Heddadj \& Gascuel-Odoux, 1999) on the variation of hydraulic properties. In contrast, natural factors such as topography, vegetation, and soil texture may have a more significant effect on steep slopes where human activity is relatively low.

The disc infiltrometer, for its suitability not only in saturated but also in unsaturated conditions as well as its water-saving and easiness to move, has been widely used to investigate the spatial variability of hydraulic properties under near-saturated conditions (Mohanty et al., 1994; Logsdon \& Jaynes, 1996). A large number of techniques are available for treating infiltration data collected from disc infiltrometers (White \& Sully, 1987; Smettem \& Clothier, 1989; Ankeny et al., 1991). Among those, multi-tensions with nonlinear regression gave fast and stable results, and did not give any negative values as verified by Logsdon et al. (1993)

Steeply sloping land is one of the main forms of land surface on the Loess Plateau in northwest China, on which soil erosion and nutrient loss can easily take place as a result of the high energy level of the fast water flow on this steep surface.

In this study, a disc infiltrometer was used to validate its potential to characterize soil hydraulic properties on a steep slope using the Loess Plateau as a sampling area. The spatial variability of hydraulic properties, including hydraulic conductivities under various pressure heads and pore size distribution (Gardner's $\alpha$ ) on steeply sloping were analyzed, in particular three aspects: (1) factors influencing hydraulic conductivity, including soil organic matter and clay contents, (2) differences among pressure heads in terms of their magnitude and spatial structure in relation to the saturated hydraulic conductivity, and (3) differences in hydraulic conductivity between the shaded and sunny aspects in terms of their magnitude and spatial structure.

\section{MATERIAL AND METHODS}

\section{Field site description}

The study was conducted at the Beigeba hillslope of the Liudaogou watershed located in the Shenmu County, Shaanxi Province, China $\left(110^{\circ} 21^{\prime} \mathrm{E}\right.$ to $110^{\circ} 23^{\prime} \mathrm{E}$; $38^{\circ} 46^{\prime} \mathrm{N}$ to $\left.38^{\circ} 51^{\prime} \mathrm{N}\right)$. The Ust-Sandiic Entisol is loess-derived and of easy erosion. As a result, the region is characterized by steep gullies and hills (Tang et al., 1993). The slope used in this study had a length of $280 \mathrm{~m}$ and runs generally downward from east to west. Disc infiltration tests were carried out on the lower $160 \mathrm{~m}$ of the slope, over which purple medic (Medicago sativa L.) of 30 years of age is being converted to couch grass as the dominant vegetation. More information about this area can be found in Hu et al. (2008).

\section{Sampling and measurement}

A total of 106 points was selected at the lower part of the slope, located at the intersections of seven sampling columns and seventeen sampling rows in two perpendicular directions, covering a total area of 60 $\mathrm{m} \times 160 \mathrm{~m}$. At each sampling location, a disc infiltrometer (50 mm radius with a reservoir tube of radius of $1.7 \mathrm{~cm}$ ) was used to determine the water infiltration rate under different pressure heads at soil surface, in the ascending sequence $(-15,-9,-6,-3,0$ $\mathrm{cm})$. Cumulative infiltration was recorded every minute until steady infiltration was nearly reached.

After the infiltration measurements were completed, soil samples of the layer $0-5 \mathrm{~cm}$ were collected near the infiltration measurement point, with a $5 \mathrm{~cm}$ diameter hand auger. After air-dried, soil samples were all sieved through a $1 \mathrm{~mm}$ sieve for laboratory analysis. Soil organic matter content was measured by the potassium dichromate method and soil particle size analysis with MaterSizer2000 laser particle size ana- 
lyzer produced by Malvern. Physical clay $(<0.01 \mathrm{~mm})$ content was calculated based on the result of particle size distribution.

\section{Infiltration data analysis}

Non-linear regression methods were used to determine the hydraulic properties of the soil at each location, for the used multiple pressure heads (Logsdon \& Jaynes, 1993). The main advantage of the method of the infiltrometer is that the hydraulic parameters have to be acquired only under steady infiltration rate, and it does not need neither initial nor final soil water contents, and does also not need the relationship of the accumulative infiltration with time. This method is mainly based on Wooding's analytical solution (Wooding, 1968) and Gardner's exponential model (Gardner, 1958). Assuming that the hydraulic conductivity under initial conditions is small enough to satisfy the condition of $K_{\text {wet }}>>K_{d r y}$, under a given applied pressure, Wooding's equation can be expressed as:

$Q\left(h_{f}\right)=\pi R^{2} K\left(h_{f}\right)+4 R \phi\left(h_{f}\right)$

where $Q\left(h_{f}\right)$ is the steady infiltration rate $\left(\mathrm{L}^{3} \mathrm{~T}^{-1}\right), R$ is the radius of the disc infiltrometer $(\mathrm{L}), K\left(h_{f}\right)$ is the hydraulic conductivity at the applied pressure head $h_{p}$ and $\phi\left(h_{f}\right)$ is the matrix flux potential $\left(\mathrm{L}^{2} \mathrm{~T}^{-1}\right)$.

Gardner' exponent function can be written as:

$K\left(h_{f}\right)=K\left(h_{0}\right) \exp (\alpha h)$

where $\alpha$ is a constant which characterizes the soil pore size distribution $\left(\mathrm{L}^{-1}\right)$, and $K\left(h_{0}\right)$ is the saturated hydraulic conductivity $\left(\mathrm{L} \mathrm{T}^{-1}\right)$. Combining Equation (1) with (2) gives

$\mathrm{Q}\left(h_{f}\right) /\left(\pi R^{2}\right)=K\left(h_{0}\right) \exp (\alpha h)+4 K\left(h_{0}\right) \exp (\alpha h) /$ $(\pi R a)$

with two unknowns, $\alpha$ and $K\left(h_{0}\right)$.

According to Equation (3), with steady infiltration rates under different applied pressure heads, $\alpha$ and $K\left(h_{0}\right)$ can be obtained by non-linear regression. Therefore, a series of disk infiltration tests were conducted with an ascending sequence of pressure heads $-15,-9,-6,-3,0 \mathrm{~cm}$. In this way, $\alpha$ and $K\left(h_{0}\right)$ can be obtained fitting $\mathrm{Q}\left(h_{f}\right) v s h$ infiltration data. After removing results which failed the statistical significance test, 99 results of $\alpha$ and $K\left(h_{0}\right)$ were available to be applied to Equation (2), which lead to hydraulic conductivities at the pressure different heads. For the purposes of this presentation the hydraulic conductivities at pressure heads of $-15,-9,-6,-3,0 \mathrm{~cm}$ will be expressed as $K_{15}, K_{9}, K_{6}, K_{3}, K_{s}$, respectively.

\section{Spatial analysis approach}

Classical and geo-statistical analyses were com- bined in this study to characterize spatial variability of the hydraulic properties. The coefficient of variation $(\mathrm{CV} \%)$ can be used to qualitatively ascertain the magnitude of the spatial variability as weak when $C V \% \leq$ $10 \%$, moderate if $10 \%<C V \%<100 \%$, and strong for $C V \% \geq 100 \%$. When geo-statistical methods are used, the magnitude of variation and spatial structure can be better determined quantitatively. Based on the regionalized variables theory and intrinsic hypothesis, a semi-variogram, $\gamma(h)$, of $\mathrm{n}$ spatial observations $z\left(x_{i}\right), \mathrm{i}=1, \mathrm{n}=1, \ldots \mathrm{n}$ can be expressed as

$\gamma(h)=1 /(2 N(h)) \sum_{i=1}^{N(h)}\left[z\left(x_{i}\right)-z\left(x_{i}+h\right)\right]^{2}$

where $N(h)$ is the number of pairs of observations separated by a distance $h$ (Grego et al., 2006). Theoretical semi-variogram models were employed to fit the semi-variance and generate geo-statistical parameters, including nugget variance $\left(C_{0}\right)$, sill variance $\left(C_{0}+C_{1}\right)$, and range $(R)$.

The degree of spatial dependence $(G D)$ was calculated as:

$G D=\left[C_{0} /\left(C_{0}+C_{1}\right)\right] \times 100$

The GD represent the spatial randomness and can be used to classify the spatial dependence as strong if $G D<25 \%$, moderate for $G D$ ranging from $26 \%$ to $75 \%$, and weak if $G D>75 \%$ (Cambardella et al., 1994).

\section{RESULTS AND DISCUSSION}

\section{Classical statistical analysis}

Summary statistics for the entire study area Most filed measured hydraulic parameters have shown to be log-normally distributed (Sisson et al., 1981; Mallants et al., 1997). In this study, the statistical frequency distributions for all hydraulic parameters conform either to normal or to log-normal distributions as judged by Q-Q plots (data not shown), in agreement with Gimenez et al. (1999). Therefore, no data transformation was performed before analysis. The classical statistical properties of the hydraulic parameters (Table 1 ) show that $\alpha$ has moderate variability ( $C V \%$ of $47.5 \%$ ) with a mean of $0.0804 \mathrm{~cm}^{-1}$. The means of the hydraulic conductivities under pressure heads of $0 ;-3 ;-6 ;-9 ;-15 \mathrm{~cm}$ were $29.97 ; 22.71 ; 17.46$; 13.59; $8.51 \mathrm{~mm} \mathrm{~h}^{-1}$, and $C V \%$ of $65.9 ; 58.1 ; 52.7$; 49.4; 48.5\%, respectively, which demonstrates moderate variability as well.

The above results indicate that the variability of $\alpha$ was weaker than that of the hydraulic conductivities at all pressure heads, which means that $\alpha$ was 
relatively homogeneous on the slope scale. After plotting the $C V \%$ of the hydraulic conductivity versus pressure heads (Figure 1), it was concluded that the hydraulic conductivity variability decreased with decreasing pressure heads, indicating that the distribution of smaller pore sizes would be more uniform than of larger ones since the dominant pore size governing water flow in soils decreases with decreasing pressure heads. However, Mohanty et al. (1994) found that the $\mathrm{CV} \%$ of the hydraulic conductivity between rows compacted by wheel traffic was greater at $-150 \mathrm{~mm}$ than at higher pressure heads. They attributed this to the relatively homogeneous larger pores as a result of destruction by the wheels.

Organic matter content (OM) and clay $(<0.01$ $\mathrm{mm}$ ) content are taken as the main factors influencing soil hydraulic conductivity. The correlation analysis showed a significant negative correlation between the organic matter content and hydraulic conductivities for all pressures (Table 2). As the supply pressure head decreased, organic matter played an increasingly important part in the water flow, as indicated by the increased correlation coefficient. Thus, in similar re-

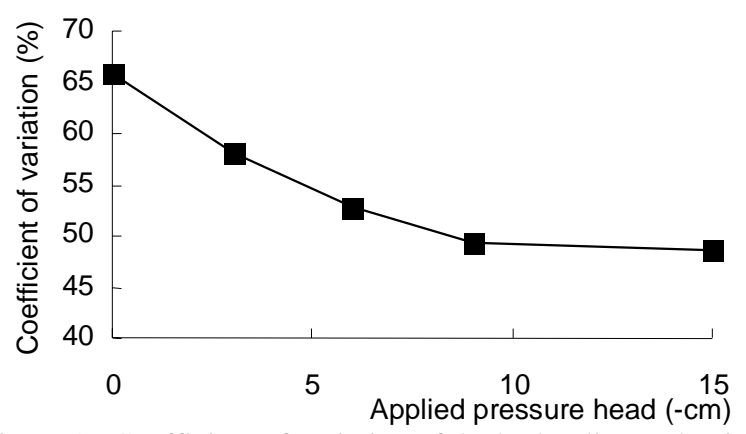

Figure 1 - Coefficient of variation of the hydraulic conductivity (K) under pressure heads. gions, OM can be beneficial for the storage of soil water by limiting infiltration into deeper soil layers. This phenomenon is important for light textured soils in arid and semi-arid regions, where soil moisture tends to be the critical factor affecting vegetative growth. As for the relationship of clay content and hydraulic conductivity, significant $(P<0.01)$ negative correlations were also found for all the pressure heads (Table 2), indicating that clay particles do not facilitate infiltration near saturated conditions. Therefore, clay can also contribute to the storage of soil water by decreasing downward water flow in the form of redistribution and upward flow in the form of evaporation. The correlation increased as the applied pressure head decreased. This indicates that water flow is more likely to be affected by soil clay content as the soil becomes drier.

Variability of hydraulic parameters along the slope - Seven estimates for hydraulic parameters were obtained for each row averaging the values per row. The Gardner's $\alpha$ index generally presented a fluctuant variation in the direction of the slope, and the hydraulic conductivities under all pressure heads decreased in general (Figure 2). As the applied pressure head decreased, the difference in the hydraulic conductivities of up and down-slope positions decreased but the distribution trend remained the same. For a better understanding of this tendency, organic matter content and clay $(<0.01 \mathrm{~mm})$ content were also scattered along the toposequence in Figure 3. Both organic matter and clay $(<0.01 \mathrm{~mm})$ content tended to decrease from the top of the slope to the bottom, which may explain the decline in hydraulic conductivities, since both factors had negative effects on the hydraulic conductivities. In addition, soil moisture tends to increase slope downward (Hu et al., 2006). This may also influence the distri-

Table 1 - Summary of $\alpha$ and hydraulic conductivity (K) statistics for the entire study area.

\begin{tabular}{lcccccc}
\hline & $\alpha$ & $K_{\mathrm{s}}$ & $K_{3}$ & $K_{6}$ & $K_{9}$ & $K_{15}$ \\
\hline Mean & $\mathrm{cm}^{-1}$ & -19.0 & 22.71 & 17.46 & 13.59 & 8.51 \\
Standard deviation & 0.0804 & 29.97 & 13.20 & 9.20 & 6.72 & 4.13 \\
Coefficient of variation (\%) & 0.0382 & 19.73 & 58.1 & 52.7 & 49.4 & 48.5 \\
\hline
\end{tabular}

$K_{s}, K_{3}, K_{6}, K_{9}, K_{15}$ are the hydraulic conductivities at pressure heads of 0, -3, -6, -9, $-15 \mathrm{~cm}$, respectively.

Table 2 - Soil organic matter (OM) and clay contents and their correlation coefficients with hydraulic conductivity.

\begin{tabular}{lcccccccc}
\hline & \multirow{2}{*}{ Mean } & \multirow{2}{*}{$\begin{array}{c}\text { Standard } \\
\text { deviation }\end{array}$} & \multirow{2}{*}{$\begin{array}{c}\text { Coefficient of } \\
\text { variation }(\%)\end{array}$} & \multicolumn{5}{c}{ Pearson correlation coefficient } \\
\cline { 5 - 9 } & & & $K_{\mathrm{s}}$ & $K_{3}$ & $K_{6}$ & $K_{9}$ & $K_{15}$ \\
\hline OM (\%) & 0.722 & 0.241 & 33.8 & $-0.319 * *$ & $-0.346 * *$ & $-0.366 * *$ & $-0.377 * *$ & $-0.393 * *$ \\
Clay (\%) & 17.649 & 4.560 & 25.8 & $-0.328 * *$ & $-0.363 * *$ & $-0.382 * *$ & $-0.384 * *$ & $-0.404 * *$ \\
\hline
\end{tabular}

${ }^{* *}$ Significant $(P<0.01) K_{s}, K_{3}, K_{6}, K_{9}, K_{15}$ are, respectively, the hydraulic conductivities at pressure heads of $0,-3,-6,-9$, $-15 \mathrm{~cm}$ 
bution pattern of the hydraulic conductivity through pore size changes resulting from the influence of soil moisture as a result of the shrinking and swelling (Lin et al., 1998). These results were also supported by Bagarello et al. (1999), who found a negative correlation between $\ln K_{f s}$ and water content. However, Gardner's $\alpha$ indexes did not present a monotonous distribution along the slope transect as expected, a pos-

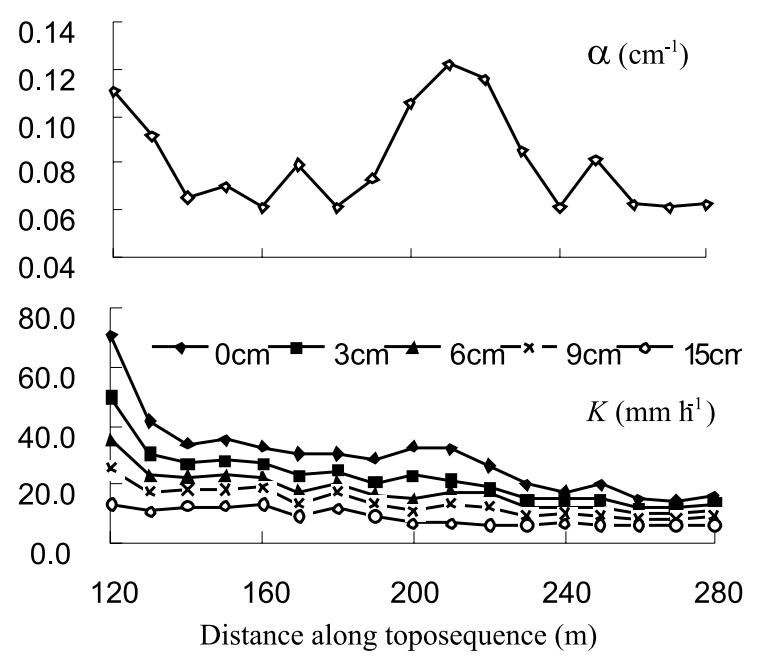

Figure 2 - Distributions of $\alpha$ and hydraulic conductivity (K) under pressure heads along the toposequence.

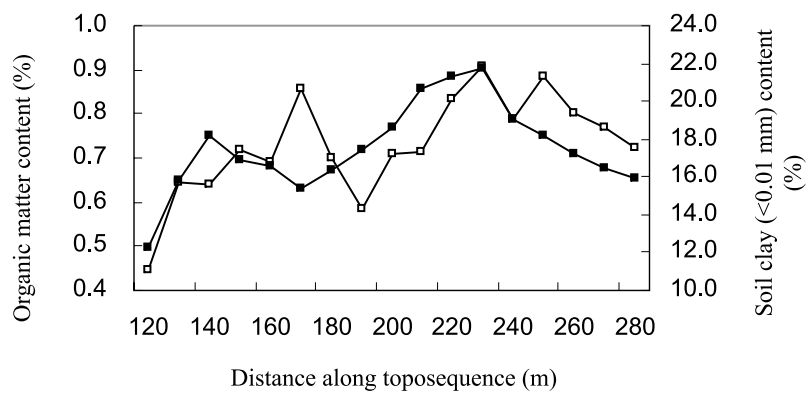

Figure 3 - Distribution of soil organic matter (line with hollow squares) and clay $(<0.01 \mathrm{~mm})$ content (line with solid squares) along the toposequence. sible reason for this being the fact that they were influenced by many complicated factors. In addition, the error introduced in the fitting procedure may also enhance the erratic pattern. Angulo-Jaramillo et al., 2000 also found that Gardner's $\alpha$ fluctuated more than $K_{f s}$ at small scales, and they attributed this to the concept that $\alpha$ is much more susceptible to capillary macropores than to $K_{f s}$.

Variability of hydraulic parameters perpendicular to slope (PS) direction - In order to present the distribution trend of the hydraulic parameters in the direction perpendicular to the slope, estimates derived from the same column were averaged to represent each column (Figure 4). Gardner's $\alpha$ of the shaded aspect of the slope were greater in relation to those of the sunny aspect. The hydraulic conductivities at high pressure heads in the middle column were lower than on either side. The middle column is situated close to a road and it may be that the larger pores in this column were destroyed by compaction caused by human traffic. Statistical analysis of $\alpha$ and hydraulic conductivity for the shaded and sunny aspects are also listed in Table 3. In order to quantify the differences in the hydraulic parameters of the two aspects, twotailed and paired t-tests were carried out. Results show that Gardner's $\alpha$ of the shaded aspect were significantly $(P<0.001)$ greater than those of the sunny aspect. The hydraulic conductivities under pressure heads of 0 and $-3 \mathrm{~cm}$ tended to be higher in the shaded aspect than in the sunny aspect, but the differences were not significant. For $-6 \mathrm{~cm}$ pressure, the hydraulic conductivities of the shaded aspect were generally lower than those of the sunny aspect, and the difference was also not significant. In contrast, the hydraulic conductivities of the shaded aspect were significantly lower than those of the sunny aspect at applied pressures of $-9 \mathrm{~cm}(P<0.05)$ and $-15 \mathrm{~cm}(P<0.001)$.

Hydraulic conductivities were mainly controlled by soil structure and texture, and other soil

Table 3 - Statistics of $\alpha$ and hydraulic conductivity (K) for shaded and sunny aspects.

\begin{tabular}{|c|c|c|c|c|c|c|c|}
\hline & & $\alpha$ & $K_{\mathrm{s}}$ & $K_{3}$ & $K_{6}$ & $K_{9}$ & $K_{15}$ \\
\hline & & $\mathrm{cm}^{-1}$ & $-\cdots-\cdots-\cdot$ & $-\cdots-$ & $\mathrm{mm} \mathrm{h}^{-1}$ & - & - \\
\hline \multirow{2}{*}{ Mean } & Shaded & 0.0986 & 34.97 & 24.89 & 18.01 & 13.24 & 7.47 \\
\hline & Sunny & 0.0667 & 28.48 & 22.95 & 18.58 & 15.11 & 10.12 \\
\hline \multirow{2}{*}{ Standard deviation } & Shaded & 0.0455 & 25.27 & 16.67 & 11.39 & 8.04 & 4.40 \\
\hline & Sunny & 0.025 & 13.47 & 9.72 & 7.18 & 5.49 & 3.63 \\
\hline \multirow{2}{*}{ Coefficient of variation, $\%$} & Shaded & 46.1 & 72.3 & 67.0 & 63.3 & 60.7 & 59.0 \\
\hline & Sunny & 32.3 & 47.3 & 42.3 & 38.6 & 36.3 & 35.8 \\
\hline $\begin{array}{l}\text { Significance level for the } \\
\text { difference of mean in two aspects }\end{array}$ & & 0.000 & 0.073 & 0.513 & 0.393 & 0.017 & 0.000 \\
\hline
\end{tabular}

$K_{\mathrm{s}}, K_{3}, K_{6}, K_{9}, K_{15}$ are, respectively, the hydraulic conductivities at pressure heads of $0,-3,-6,-9,-15 \mathrm{~cm}$ 
chemical-physical properties. As the pressure head rises, macro-pores play a much more important role in the soil water flow and the contribution of micropores to water flow decreases. Macropores are dominated by soil structure and biopores, while micro-pores are influenced by underlying physical and chemical properties related to soil texture. As analyzed above, the relative magnitude of the hydraulic conductivities between the shaded and sunny aspects differed with the applied pressure head, with hydraulic conductivities of the shaded aspect being greater than those of the sunny aspect at higher applied pressure heads and vice versa, when lower pressures were applied. In order to investigate this further, the organic matter and clay content of the sunny and shaded aspects of the slope were compared using paired t-tests (Table 4). Soil organic matter content of the shaded aspect was significantly greater than that for the sunny aspect. The clay content of the shaded aspect was slightly lower as compared to the sunny aspect, but the difference was not significant.

These results suggest that soil hydraulic properties may be affected by the variations in soil organic matter content at different positions along the slope. The higher hydraulic conductivities of the shaded aspect at pressure heads of 0 and $-3 \mathrm{~cm}$ may be affected by several factors. First, the soil in this portion of the slope had a higher number of biopores. This may favor infiltration near saturation. In contrast, the higher organic content of the shaded aspect slope may hamper infiltration near saturation. Obviously, the effects of biopores and organic matter content offset each other under higher pressure heads. At lower pressure heads, however, the influence of biopores is weakened.

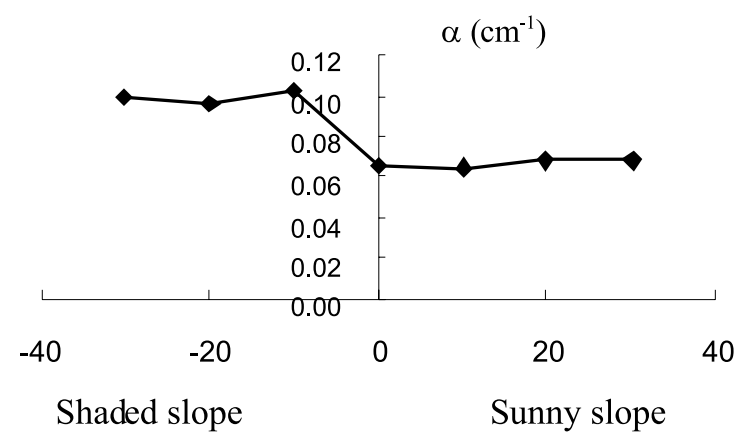

Thus the reduced hydraulic conductivity of the shaded aspect of the slope may be due to its higher soil organic matter content. The changes in the relative magnitude of the hydraulic conductivity between the shaded and sunny aspects agreed with our observation that Gardner's $\alpha$ of the shaded aspect were larger than those of the sunny aspect.

The spatial distribution of hydraulic properties in a given area may be closely associated with specific processes which have occurred in that area. Even for the same influencing factors, they may exert different influences on different areas. The correlation between organic matter and clay content with hydraulic conductivity was generally greater for the sunny aspect than for the shaded aspect (Figure 5). This suggests that other factors, such as topographic properties may contribute to the spatial variability of the hydraulic conductivity of the shaded aspect, which led to a greater heterogeneity of Gardner's $\alpha$ and hydrau-

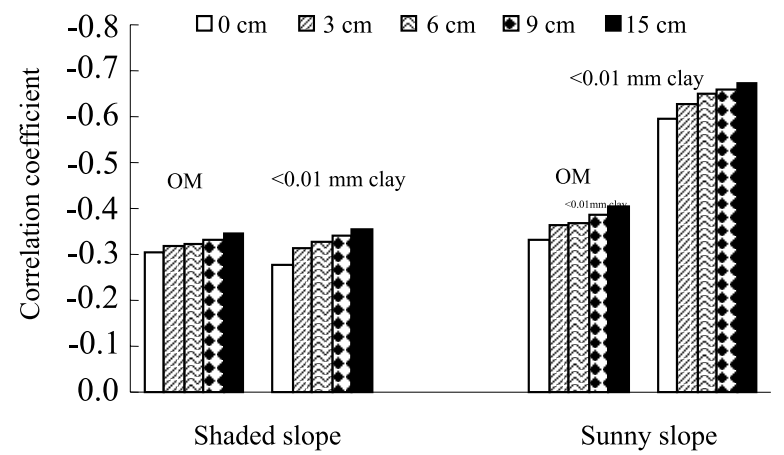

Figure 5 - Correlation coefficients of soil organic matter (OM) and clay $(<0.01 \mathrm{~mm})$ content with hydraulic conductivity under pressure heads for shaded slope and sunny slope.

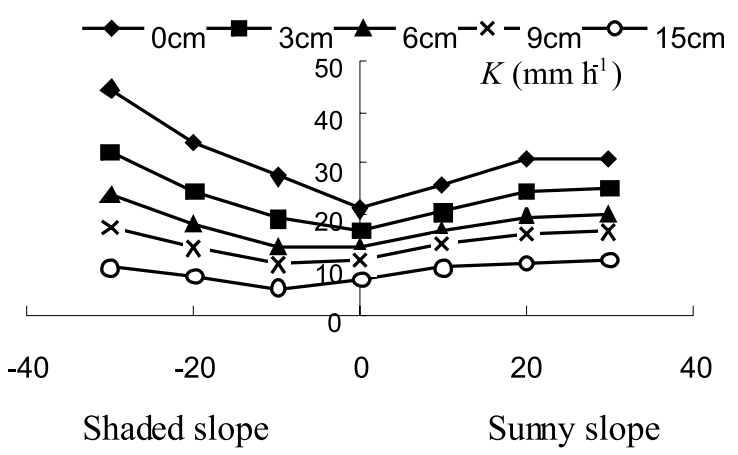

Figure 4 - Distribution of $\alpha$ and hydraulic conductivity $(K)$ along the direction perpendicular to the slope.

Table 4 - Paired-samples t-test of soil organic matter $(\mathrm{OM})$ and clay $(<0.01 \mathrm{~mm})$ content between the shaded and sunny aspects.

\begin{tabular}{lcccc}
\hline & Mean $^{+}$ & Standard deviation & Std. error mean & Level of significance \\
\hline OM & 0.187 & 0.258 & 0.044 & 0.000 \\
Clay & -0.658 & 4.967 & 0.840 & 0.438 \\
\hline
\end{tabular}

${ }^{+}$Refers to the mean value for the shaded aspect minus the mean value for the sunny aspect. 
lic conductivity on the shaded aspect as compared to the sunny aspect (Table 3). Therefore, a different strategy should be taken for different slope aspects even at the same hill-slope. For example, due to the relatively high heterogeneity of the hydraulic parameters in the shaded aspect, more processes may need to be considered and more samples may be needed to determine these hydraulic parameters in order to increase the accuracy of hydrological models.

\section{Geo-statistical analysis}

Semi-variograms of hydraulic parameters along the slope - Due to the limited sampling made perpendicular to the slope, semi-variograms of the hydraulic parameters were focused only along slope (Figure 6). Gardner's $\alpha$ showed an erratic distribution with no spatial structure along the slope. As far as the hydraulic conductivity is concerned, the semi-variance increased with increasing distance, except for 80 and $90 \mathrm{~m}$, where semi-variance values were unexpectedly low. The resulting concave line projected gradually as pres- sure head decreased. When fitting the semi-variograms to models (Table 5), it was found that there were no adequate models available for $K_{s}$. However, $K_{3}, K_{6}, K_{9}$, and $K_{15}$ could be well fitted using a linear model with sill for pressure heads of $-3,-6$, and $-9 \mathrm{~cm}$ and a spherical model for pressure head of $-15 \mathrm{~cm}$. Their ranges and $G D$ changed from $110 \mathrm{~m}$ to $140 \mathrm{~m}$, and from $12.03 \%$ to $4.05 \%$. This indicates that they all showed strong spatial dependency.

Based on reports from the literature, Sobieraj et al. (2004) compared the spatial structure of saturated hydraulic conductivity data and showed that semi-variogram ranges were between 0 and $115 \mathrm{~m}$ and values for $G D$ ranged from $6 \%$ and $100 \%$. Results here obtained were comparable to theirs. However, it may be considered that the ranges are somewhat larger as compared to our sampling extent (160 m). This may be attributed to the relatively large sampling space (10 $\mathrm{m})$, which could have a significant scaling effect (Blöschl \& Sivapalan, 1995). However, in this study, more interest was placed in the relative spatial struc-

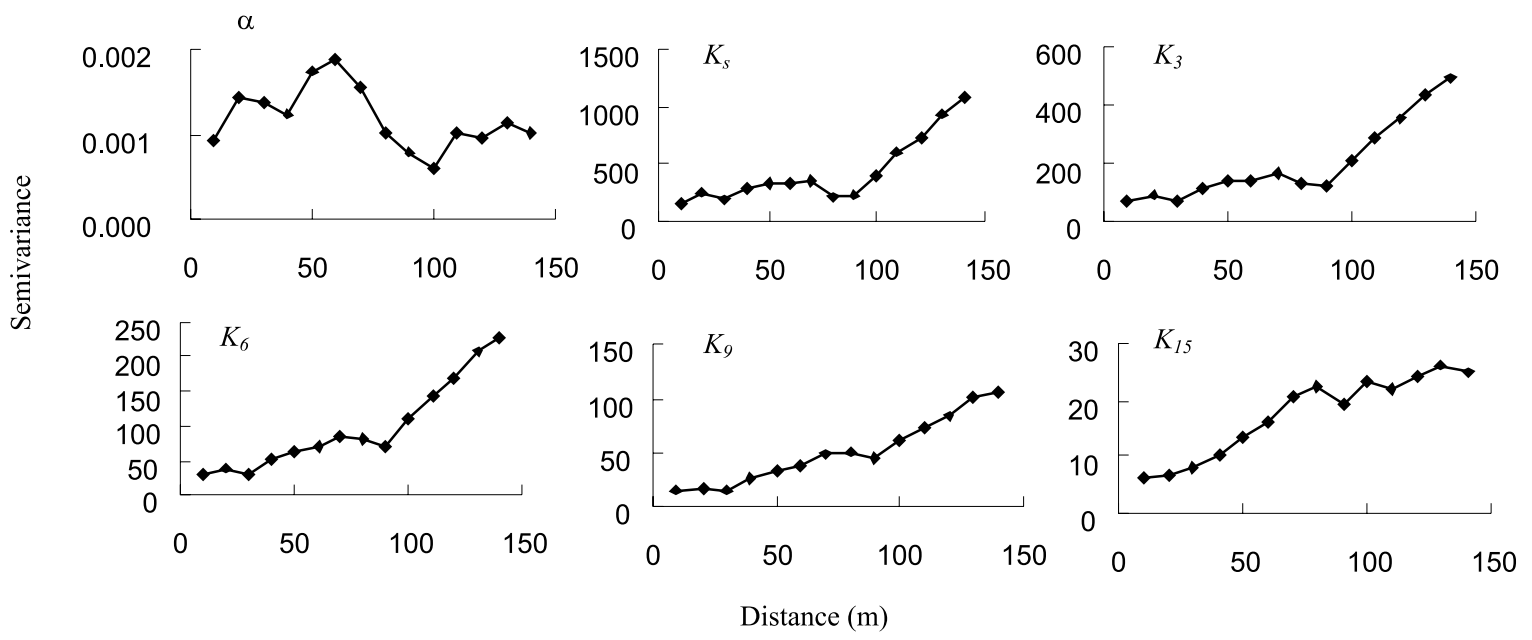

Figure 6 - Semi-variograms of $\alpha$ and hydraulic conductivity $(K)$ in the direction along slope.

Table 5 - Semi-variogram parameters of $\alpha$ and hydraulic conductivity $(K)$ in the direction along slope.

\begin{tabular}{lcccccc}
\hline \multicolumn{1}{c}{ Parameter } & $\alpha^{+}$ & $K_{\mathrm{s}}^{+}$ & $K_{3}$ & $K_{6}$ & $K_{9}$ & $K_{15}$ \\
\hline Model & $\mathrm{cm}^{-1}$ & $-\ldots-1$ & $\mathrm{~L}$ & $\mathrm{~L}$ & $\mathrm{~L}$ & $\mathrm{~S}$ \\
$C_{0}$ & $\mathrm{No}$ & $\mathrm{No}$ & -16.75 & 14.37 & 4.29 & 2.23 \\
$C_{1}$ & - & - & 342.01 & 172.56 & 97.41 & 55.06 \\
$G D(\%)$ & - & - & 12.03 & 7.69 & 4.23 & 4.05 \\
Range $(\mathrm{m})$ & - & - & 110 & 110 & 120 & 140 \\
F & - & - & 42.52 & 67.82 & 110.17 & 87.78 \\
$\mathrm{R}^{2}$ & - & - & 0.8948 & 0.9313 & 0.9566 & 0.9461 \\
\hline
\end{tabular}

${ }^{+}$No appropriate model was found, "L" refers to the linear with sill model, "S" refers to the spherical model. $C_{0}$ : nugget variance, $C_{1}$ : structure variance, $G D=\left(C_{0} /\left(C_{0}+C_{1}\right)\right) \times 100 . K_{s}, K_{3}, K_{6}, K_{9}, K_{15}$ are, respectively, the hydraulic conductivities at pressure heads of 0 , $-3,-6,-9,-15 \mathrm{~cm}$. 
ture rather than the exact values among different pressure heads. Therefore, it is concluded that as pressure heads decrease, the correlation length and the spatial dependency is enhanced. This is due to the fact that as the applied pressure head drops, the corresponding flow is progressively governed by intrinsic soil properties such as particle size distribution. This was reflected by the increasing correlation between the hydraulic conductivity and soil clay content (Table 2). Obviously, intrinsic soil properties tend to be more spatially dependent than other environmental factors.
Comparison of the spatial structure of hydraulic parameters between the shaded and sunny aspects of the slope - The semi-variograms of hydraulic parameters in the shaded and sunny aspects and their corresponding fitting results are presented in Figure 7 and Table 6, respectively. The structure variance $C_{1}$ of each hydraulic property in the shaded aspect was greater than in the sunny aspect, which is in agreement with results from classical statistical analysis, showing that heterogeneity in the shaded aspect was greater than in the sunny aspect. The dif-

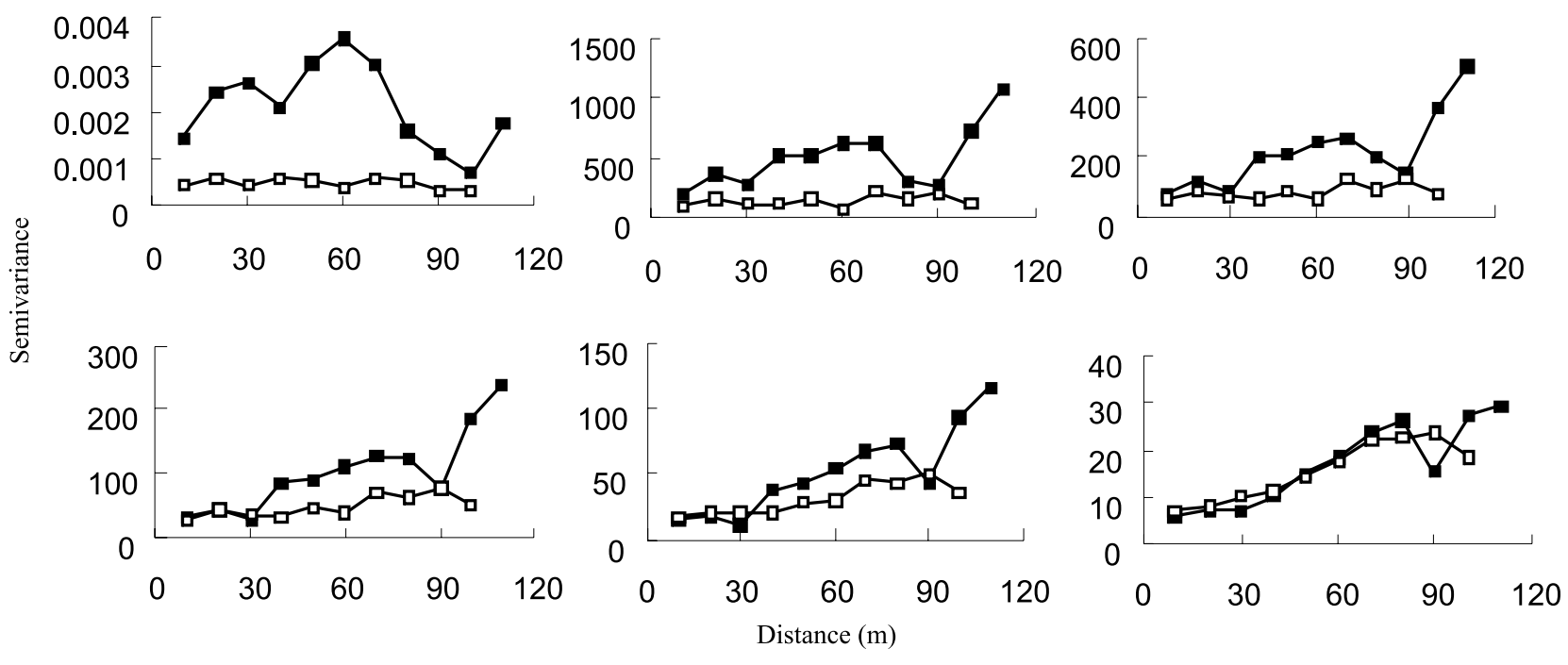

Figure 7 - Comparison of semi-variograms of $\alpha$ and hydraulic conductivity (K) between shaded and sunny slopes (Hollow squares refer to the sunshine slope and solid squares to the shadow slope).

Table 6 - Comparison of Semi-variogram parameters of $\alpha$ and hydraulic conductivity $(K)$ between the shaded and sunny aspect.

\begin{tabular}{|c|c|c|c|c|c|c|c|}
\hline Parameter & Aspect & $\alpha^{+}$ & $K_{\mathrm{s}}^{+}$ & $K_{3}$ & $K_{6}$ & $K_{9}$ & $K_{15}$ \\
\hline \multirow{3}{*}{ Model } & & $\mathrm{cm}^{-1}$ & - & . & $--\mathrm{mm} \mathrm{h}^{-1}-$ & - & - \\
\hline & Shaded & - & - & $\mathrm{L}$ & $\mathrm{L}$ & $\mathrm{L}$ & $\mathrm{S}$ \\
\hline & Sunny & - & - & $\mathrm{L}$ & $\mathrm{L}$ & $\mathrm{L}$ & $\mathrm{L}$ \\
\hline \multirow{2}{*}{$C_{0}$} & Shaded & - & - & 68.26 & 19.96 & 4.63 & 1.81 \\
\hline & Sunny & - & - & 65.87 & 30.55 & 14.39 & 4.24 \\
\hline \multirow{2}{*}{$C_{1}$} & Shaded & - & - & 437.41 & 189.45 & 99.70 & 22.32 \\
\hline & Sunny & - & - & 40.41 & 35.40 & 29.06 & 17.60 \\
\hline \multirow{2}{*}{$G D(\%)$} & Shaded & - & - & 13.5 & 9.5 & 4.4 & 3.86 \\
\hline & Sunny & - & - & 62.0 & 46.3 & 33.1 & 19.4 \\
\hline \multirow{2}{*}{ Range (m) } & Shaded & - & - & 100 & 90 & 90 & 100 \\
\hline & Sunny & - & - & 60 & 60 & 60 & 90 \\
\hline \multirow{2}{*}{$\mathrm{F}$} & Shaded & - & - & 15.26 & 22.67 & 25.68 & 19.46 \\
\hline & Sunny & - & - & 4.77 & 13.22 & 28.66 & 62.68 \\
\hline \multirow{2}{*}{$\mathrm{R}^{2}$} & Shaded & - & - & 0.7923 & 0.8500 & 0.8652 & 0.8295 \\
\hline & Sunny & - & - & 0.5768 & 0.7907 & 0.8912 & 0.9471 \\
\hline
\end{tabular}

${ }^{+}$No appropriate model was found, "L" refers to the linear with sill model, "S" refers to the spheric model. $C_{0}$ : nugget variance, $C_{1}$ : structure variance, $G D=\left(C_{0} /\left(C_{0}+C_{1}\right)\right) \times 100 . K_{s}, K_{3}, K_{6}, K_{9}, K_{15}$ are, respectively, the hydraulic conductivities at pressure heads of 0 , $-3,-6,-9,-15 \mathrm{~cm}$. 
ference of heterogeneity between the shaded and sunny aspects decreased as the applied pressure head decreased. Under a pressure head of $-15 \mathrm{~cm}$, the spatial structure of hydraulic conductivity behaved similarly. As for the values for $G D$, they were lower on the shaded aspect, which is comparable to the entire slope as expressed in Table 5, showing a high magnitude of spatial dependence. In contrast, the sunny aspect exhibited obviously higher values which showed a moderate spatial dependence for hydraulic conductivities at $-3 \mathrm{~cm},-6 \mathrm{~cm}$, and $-9 \mathrm{~cm}$ and a strong spatial dependence for $-15 \mathrm{~cm}$. However, regardless of whether it was the shaded or sunny, the $G D$ ratio decreased as the pressure head decreased from $-3 \mathrm{~cm}$ to $-15 \mathrm{~cm}$. Furthermore, the values for the shaded aspect remained consistently lower than those for the sunny aspect. This demonstrates that the spatial dependence became much stronger as pressure head decreased and the spatial structure of the shaded aspect was stronger than that of the sunny aspect. Since the nugget, structure variance, and $G D$ values of the shaded aspect were similar to the values for the whole slope, we assume that the spatial structure of the shaded aspect may dominate the entire slope.

Many studies have attempted to explain $G D$ with $K_{\mathrm{s}}$ semivarigrams and they attribute the variability mainly to the human activity (Tsegaye \& Hill, 1998; Mohanty \& Mousli, 2000). The area of this study has been deviated from farming activities for about 30 years and was therefore less influenced by human activity. This is likely to be the main reason for the lower nugget variance and the strong spatial dependency on the whole slope scale, especially at low pressure heads.

\section{ACKNOWLEDGMENTS}

To the National Natural Sciences Foundation of China Grant numbers of 90502006 and 50479063 and the "Hundred Talents Program" of the Chinese Academy of Sciences for the financial support.

\section{REFERENCES}

ANGULO-JARAMILLO, R.; VANDERVAERE, J.P.; ROULIER, S.; THONY, J.L.; GAUDET, J.P.; VAUCLIN, M. Field measurement of soil surface hydraulic properties by disc and ring infiltrometers: a review and recent developments. Soil \& Tillage Research, v.55, p.1-29, 2000.

ANKENY, M.D.; AHMED, M.; KASPAR, T.C.; HORTON, R. Simple field method for determining unsaturated hydraulic conductivity. Soil Science Society of America Journal, v.55, p.467-470, 1991.

BAGARELLO, V.; CASTELLINI, M.; IOVINO, M. Influence of the pressure head sequence on the soil hydraulic conductivity determined with tension infiltrometer. Applied Engineering in Agriculture, v.21, p.383-391, 2005.
BAGARELLO, V.; IOVINO, M.; REYNOLDS, W.D. Measuring hydraulic conductivity in a cracking clay soil using the Guelph Permeameter. Transactions of the ASAE, v.42, p.957-964, 1999.

BLÖSCHL, G.; SIVAPALAN, M. Scale issues in hydrological modeling: a review. Hydrological Process, v.9, p.251-290, 1995.

CAMBARDELLA, C.; MOOMAN, T.B.; NOVAK, J.M.; PARKIN, T.B.; KARLEM, D.L.; TURVO, R.F.; KONOPA, A.E. Field scale variability of soil properties in central Iowa soil. Soil Science Society of America Journal, v.47, p.1501-1511, 1994.

GARDNER, W.R. Some steady state solutions of the unsaturated flow equation with application to evaporation from a water table. Soil Science, v.85, p.228-232, 1958.

GIMENEZ, D.; RAWLS, W.J.; LAUREN, J.G. Scaling properties of saturated hydraulic conductivity in soil. Geoderma, v.88, p.205-220, 1999.

GREGO, C.R.; VIEIRA, S.R.; ANTONIO, A.M.; ROSA, S.C.D. Geostatistical analysis for soil moisture content under the no tillage cropping system. Scientia Agricola, v.63, p.341-350, 2006.

HEDDADJ, D.; GASCUEL-ODOUX, C. Topographic and seasonal variations of unsaturated hydraulic conductivity as measured by tension disc infiltrometers at the field scale. European Journal of Soil Science, v.50, p.275-283, 1999.

HU, W.; SHAO, M.A.; WANG, Q.J. Study on spatial variability of soil moisture on the recultivated slope-land on the Loess Plateau. Advances in Water Science, v.17, p.74-81, 2006.

HU, W.; SHAO, M.A.; WANG, Q.J.; REICHARDT, K. Soil water content temporal-spatial variability of the surface layer of a Loess Plateau hillside in China. Scientia Agricola, v.65, p.277289, 2008

LIN, H.S.; McLNNES, K.J.; WILDING, L.P.; HALLMARK, C.T. Macroporosity and initial moisture effects on infiltration rates in vertisols and vertic intergrades. Soil Science, v.163, p.2-8, 1998.

LOGSDON, S.D.; JAYNES, D.B. Methodology for determing hydraulic conductivity with tension infiltrometers. Soil Science Society of America Journal, v.57, p.1426-1431, 1993.

LOGSDON, S.D.; JAYNES, D.B. Spatial variability of hydraulic conductivity in a cultivated field at different times. Soil Science Society of America Journal, v.60, p.703-709, 1996.

MALLANTS, D.; MOHANTY, B.P.; VERVOORT, A.; FEYEN, J. Spatial analysis of saturated hydraulic conductivity in a soil with macropores. Soil Technology, v.10, p.115-131, 1997.

MOHANTY, B.P.; ANKENY, M.D.; HORTON, R.; KANWAR, R.S Spatial analysis of hydraulic conductivity measured using disc infiltrometers. Water Resources Research, v.30, p.24892498, 1994.

MOHANTY, B.P.; MOUSLI, Z. Saturated hydraulic conductivity and soil water retention properties across a soil-slope transition. Water Resources Research, v.36, p.3311-3324, 2000.

SISSON, J.B.; WíERENGA, P.J. Spatial variability of steady-state infiltration rates as a stochastic process. Soil Science Society of America Journal, v.45, p.699-704, 1981.

SMETTEM, K.R.J.; CLOTHIER, B.E. Measuring unsaturated sorptivity and hydraulic conductivity using multiple disc permeameters. Soil Science, v.40, p.563-568, 1989.

SOBIERAJ, J.A.; ELSENBEER, H.; CAMERON, G. Scale dependency in spatial patterns of saturated hydraulic conductivity. CATENA, v.55, p.49-77, 2004.

TANG, K.L.; HOU, Q.C.; WANG, B.K. The environment background and administration way of wind-water erosion crisscross region and Shenmu experimental area on the Loess Plateau. Memoir of NISWC, v.18, p.2-15, 1993.

TSEGAYE, T.; HILL, R.L. Intensive tillage effects on spatial variability of soil physical properties. Soil Science, v.163, p.143-154, 1998.

WHITE, I.; SULLY, M.J. Macroscopic and microscopic capillary length and time scales from field infiltration. Water Resources Research, v.23, p.1514-1522, 1987.

WOODING, R.A. Steady infiltration from a shallow circular pond. Water Resources Research, v.4, p.1259-1273, 1968.

Received May 18, 2007

Accepted November 29, 2007 